고신대학교 의과대학 호흡기내과

장 태 원

\title{
Autofluorescence Bronchoscopy
}

Tae Won Jang, M.D.

Departments of Internal Medicine College of Medicine, Kosin University, Busan, Korea

\section{서 론}

폐암은 점점 증가하는 암으로 한국에서만도 매년 8,000 건 이상의 새로운 환자가 발생하고 있고 전체 사 망률이 가장 높은 암이다. 폐암은 5년 생존율이 $15 \%$ 미만으로 예후가 매우 불량한 암종으로 치료 방법의 발전도 중요하지만 ${ }^{2}$ 향후 방향은 흡연율의 감소를 통 한 질병의 예방과 근치 치료가 가능한 조기 병기에 암 을 발견하는 것이 중요하다. Saccomanno 등이 처음 으로 기관지 조직은 atypical metaplasia(화성)에서 dysplasia(형성이상), carcinoma in situ(CIS)로 발전 하여 invasive carcinoma 진행함으로 기술하였다. 자 궁 경부암, 대장암은 조기 병변을 발견하고 치료함으 로써 암관련 사망률을 의미있게 줄일 수 있음을 보고 하였으나,5, 불행하게도 폐암의 경우 생존율 향상을 보여주지 못하여 객담 세포진 검사나 흥부 방사선, 기 관지경 같은 검사는 이제 검진 목적으로 사용되고 있 지 않고 있다. 최근 조기 검진 방법으로 고해상도 CT, 혈청 생물학적 표지자들, 객담 $\mathrm{DNA}$ 등이 사용되고 있으나 그 역할은 아직 정립이 필요하다 ${ }^{6,7}$. 기관지경 이 조기 병변의 발견에 도움을 줄 수 있는 이유는 첫 째, carcinogenesis는 수 년에 걸쳐 진행하고 ${ }^{3}$, 둘째, 50-60\%의 폐암 특히 편평세포암이 중심 기도에 많이 발생하기 때문이다. 중심기도 종양은 기관지경에 발 견이 되나 일반적인 방사선학적 사진에서 발견이 어 렵고 ${ }^{8}$, 일반 백색 내시경은 조기 병변의 발견에 낮은 예민도가 문제이다. 조기 병변은 아주 작고 몇몇 세

Address for correspondence: Tae Won Jang, M.D. Department of Internal Medicine, Kosin University College of Medicine, 34 Amnam-dong, Suh-gu, Busan 602-702, Korea

Phone: 82-51-990-6637, Fax: 82-51-248-5686

E-mail: jangtw@ns.kosinmed.or.kr
포층으로만 이루어져 있고 ${ }^{10}$, 내시경상 병변의 변화가 미세하여 경험이 풍부한 기관지경 검사자라도 놓치는 경우가 많다. 객담 세포진 검사가 양성인 경우 일반 기관지경 검사에서 병변을 발견하지 못하면 여러 장 소를 무분별하게 조직검사를 실시하나 너무 시간적 소비가 많은 문제점이 있다. 이런 발견이 어려운 조기 폐암의 발견율을 높이기 위하여 형광기관지경이 도입 되었다 ${ }^{11}$. 자가 형광 기관지경은 중심 기도의 조기 병 변을 발견하는 내시경 기구로 그 장비의 종류 및 사용 의의에 대하여 알아보고자 한다.

\section{장비 및 방법}

기관지경 검사와 동일한 방법으로 국소 마취를 사 용하여 진정제를 투여하면서 시행할 수 있다. 전 세계 적으로 출시되어 있는 기종은 5 개 기종이나 가장 많 이 사용되고 있는 것은 Lung Imaging Fluorescence Endoscopic device(LIFE)와 D-light/AFB system이 다. 통상 요즘은 자가 형광기관경을 이용하며 5aminoleuvulinic acid(ALA)같은 광과민 약제를 사용 하지 않고 실시한다. 그러나 색의 대비가 명확하지 못 한 경우가 많아 $\mathrm{ALA}$ 를 흡입 후 형광 기관지경 검사 를 실시하여 조금 더 명확한 구분을 하기 위한 시도를 하고 있다. 정상 점막의 색은 녹색의 형광을 발생하나 dysplasia나 carcinoma의 비정상 조직은 적색/갈색의 형광이 나타나게 된다. 검사 방법은 먼저 백색 기관지 경을 사용하여 기관지 내부를 검사한 후에 형광 모드 로 바꾸어 자가 형광을 비추며 비정상적으로 색이 발 현되는 부위를 조사한다. 조직 검사는 비정상으로 보 이는 부위에 최소한 3 개 이상 조직검사를 실시한다. 각각의 조직 검사에는 새로운 조직 감자를 사용하여 다른 조직에 상호 오염(cross contamination)이 되는 
것을 방지하여 결과 판독에 혼란을 미리 방지하여야 한다. Karl-Storz system은 변형시킨 Xenon light source를 사용한다. LIFE와 D-light system의 유용성 을 비교한 것은 한 연구가 있으나 ${ }^{12}$ 거의 같은 결과를 나타남을 보고하였다. 그러나 사용 방법은 D-light system이 조금 더 용이한 것으로 보인다. 우리나라는 LIFE, D-light system, DAFE system을 이용한 임상 결과는 보고가 되어 있으나 ${ }^{13-15}$, 아직 Olympus와 Pentax 회사의 제품(SAFE)은 수입이 되지 않아 한국 내 보고는 없는 상태이다. Olympus사의 Autofluorescence imaging bronchoscope system(AFI)는 videoendoscope system으로 460-690 nm의 형광과 반사 빛인 $550 \mathrm{~nm}$ 의 G'와 $610 \mathrm{~nm} \mathrm{R}$ band 빛을 포함 한 세 가지 빛을 감지하여 다른 형광 기관지경에 비하 여 위양성이 많아 발생하는 만성 기관지염 등의 염증 성 병변과의 감별에 유용성이 높은 것을 보고하였다

${ }^{16}$. Pentax사의 SAFE 3000은 역시 videoendoscope system이고 Infrared cut 필터와 Beam splitter를 사 용하여 백색광과 형광을 따로 감지하여 상을 만들어 더 선명한 이미지와 조기병변 발견에 예민도를 의미 있게 높였음을 보고하였다 ${ }^{17}$.

\section{원 리}

형광 형태(chromophores)는 조직이 스스로 나오는 형광과, 전구 물질인 ALA 투여 시 조직에서 형광물 질로 바뀌는 것과, 형광물질을 직접 투여하여 발산하 는 형태로 나눌 수 있다. 형광 기관지경 시스템은 정 상조직과 암조직의 서로 다른 형태의 형광 발산에 착 안하여 자가 형광이나 외부 광과민 약제를 투여함으 로 발생하는 형광을 발견하는 방법에 기초를 두고 있 다. 먼저 소개된 광역동 진단법은 외부에서 $\mathrm{ALA}$ 를 투여하여 형광을 비추어 병변을 찾는 방법으로 피부 에 광과민 반응, 시간적 지연, 높은 경비 때문에 새로 운 방법인 자가 형광을 이용한 발견 방법을 고안하게 되었다. Lam 등 ${ }^{18}$ 이 처음으로 protoporphyrins의 사용 없이 기관지 내 병변을 발견할 수 있는 자가 형광 기 관지경을 소개하였다. 그들은 $100 \mathrm{~mW}$ helium- cadmium laser를 사용하여 blue light(442 nm)를 기도에
조명하여 적색/녹색 형광 강도를 측정하여 그 비를 이 용한 색상 차이로 조기 병변을 발견하는 방법에 사용 하였다. 적색/녹색비가 moderate dysplasia, severe dysplasia, CIS의 병변에 정상보다 의미있게 높게 적 색으로 발광하는 것을 보고하였다 ${ }^{19}$. 기관지 점막 표 면에 빛을 비추면 빛은 굴절, 반사, 흡수가 발생하고 부가적으로 조직에 형광을 유발한다. 그러나 이런 자 가 형광은 일반 백색 기관지경에는 강도가 낮고 굴절 과 산란하는 빛에 묻혀 검사자가 보이지 않아 발견을 할 수가 없다. 조직 형광은 세포 내에서 일어나는 특 히 chromophores의 전기적 구조에 따른 생화학적 변 화에 따라 다르게 나타난다. 정상 기도는 violet-blue spectrum(400-450 nm)에 폭로되면 녹색으로 보이나, 점막 하 병변이 정상에서 metaplasia, dysplasia, CIS 로 진행할수록 점진적으로 녹색을 잃고 적색-갈색으 로 기도가 변하여 보이게 된다(Figure 1, 2). 색상이 변하게 되는 기전은 특정 chromophores의 감소, 상피 세포 두께 증가, 진행성 병변에 나타나는 혈관생성의 증가가 이유 ${ }^{20}$ 가 된다(Table 1). 이 중에 혈관 생성과 관계되는 조직학적인 변화 중에 하나인 Angiogenic squamous dysplasia(ASD)는 metaplastic 혹은 dysplastic한 편평 기관지 상피 내로 모세 혈관이 들어가 는 특이한 병변이다. 이 현상은 기관지 폐암 발생의 초기에 일어날 수 있으며 LIFE를 사용할 경우는 75\% 에서 병변을 관찰할 수 있으나 일반 기관지경은 단지 $15 \%$ 에서만 발견이 가능하여 조기 병변이 적색으로 나타나는 원인이 된다 ${ }^{21}$. 상피 내(intraepithelial) 암조 직은 아주 적은 층일 수 있기 때문에 점막 표면적은

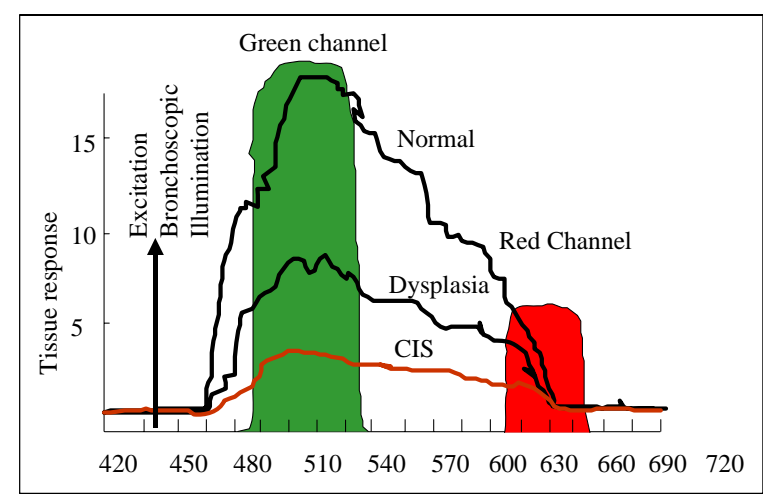

Figure 1. Spectrum of normal and preinvasive lesion. 


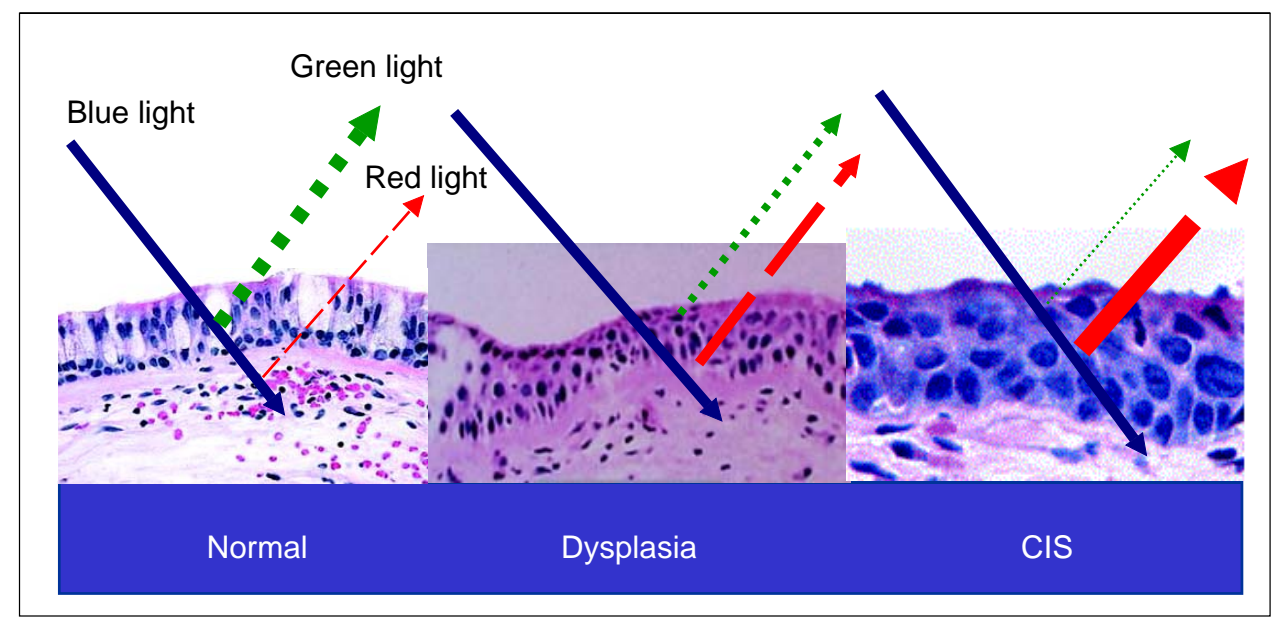

Figure 2. Progressive loss of autofluorescence with submucosal diseases (primarily green to red/brown appearance).

Table 1. Reasons for decrease in autofluorescence in preinvasive and invasive lung cancer

Decrease in fluorophore amount or quantum yield, e.g., decrease in extracellular matrix from metalloproteinases Changes in tissue architecture, e.g. increased thickness of epithelial layer Increased blood volume from increase on microvascular density

일반 기관지경일 경우 정상으로 보이는 경우가 많다. 그래서 Woolner 등른 단지 CIS의 29\%만이 경험 많 은 기관지경 검사자에서 발견이 가능하다고 보고하였다.

\section{조기 병변의 발견에 형광기관지의 역할}

형광 기관지경을 실시하는 이유 중 가장 큰 이론적 근거는 field cancerization이다. 전 호흡기 계통이 발 암물질에 노출되면 비정상적인 세포의 증식이 여러 부위에 발생하고 이 부분은 점진적으로 암을 진행하 게 되는 이론으로(Figure 3), 폐암이 발견된 병변 부 위 이외에도 다른 호흡기 기관지 조직에 새로운 형태 의 암세포가 자란다. Sato 등 ${ }^{23}$ 은 폐암이 의심되거나 객담 세포진 검사에서 양성인 환자를 대상으로 형광 기관지경을 실시한 경우 $42 \%$ 에서 여러 장소에서 병 변을 발견하였다. 기관지내 CIS의 자연적인 경과나 빈도는 아직 명확히 알려져 있지 못하다. Lam 등ㄹㅇㅣ 객담 세포진 검사에서 이상 세포가 보인 511명의 흡 연가를 대상으로 검사한 보고에서 $\mathrm{CIS}$ 는 $1.6 \%$ 에서 moderate-severe dysplasia는 19\%에서 발견이 되었
다. 객담 세포진 검사에서 비정상 세포가 보인 경우 침습성 암으로 진행은 5-10년 경과 후 8-83\%로 다양 하게 보고하고 있고, CIS에서 침습적인 종양으로 진 행하는 환자의 빈도는 불명확하나 severe dysplasia에 서 CIS로 진행하는 확율보다는 더 높은 것으로 알려 져 있다. 적은 수이지만 Venmans 등 25 의 보고에 의하 면 9명 중 5 명 $(56 \%)$ 에서 기관지내 치료에도 불구하고 $\mathrm{CIS}$ 가 침습성 암으로 진행하는 것을 보고하였다. Bota 등 ${ }^{26}$ 의 보고에 의하면 2 년간 104 명의 고위험군 환자의 416 병변을 추적한 결과 severe dysplasia를 가진 27 병변 중 3 개월에 $70 \%$ 가 퇴행(regression)하 였고 2년에 $37 \%$ 가 그대로 있거나 진행하였으나, $41 \%$ 에서는 정상으로 돌아갔고 $22 \%$ 가 low-grade dysplasia로 퇴행되었으며, CIS의 32 병변은 3개월에 25 (78\%)예가 severe dysplasia/CIS로 그대로 남아 있어 치료를 실시하였고 2 년 검사에서 퇴행했던 7 병변 중 에서 2 자리에서 재발을 하였다. 이들은 진행의 예측 인자로 병변이 CIS이거나 이전 폐암이나 두경부 종양 이 있는 경우로 보고를 하였다. 이것을 근거로 조기 병변의 추적 검사는 low-grade dysplasia인 경우는 


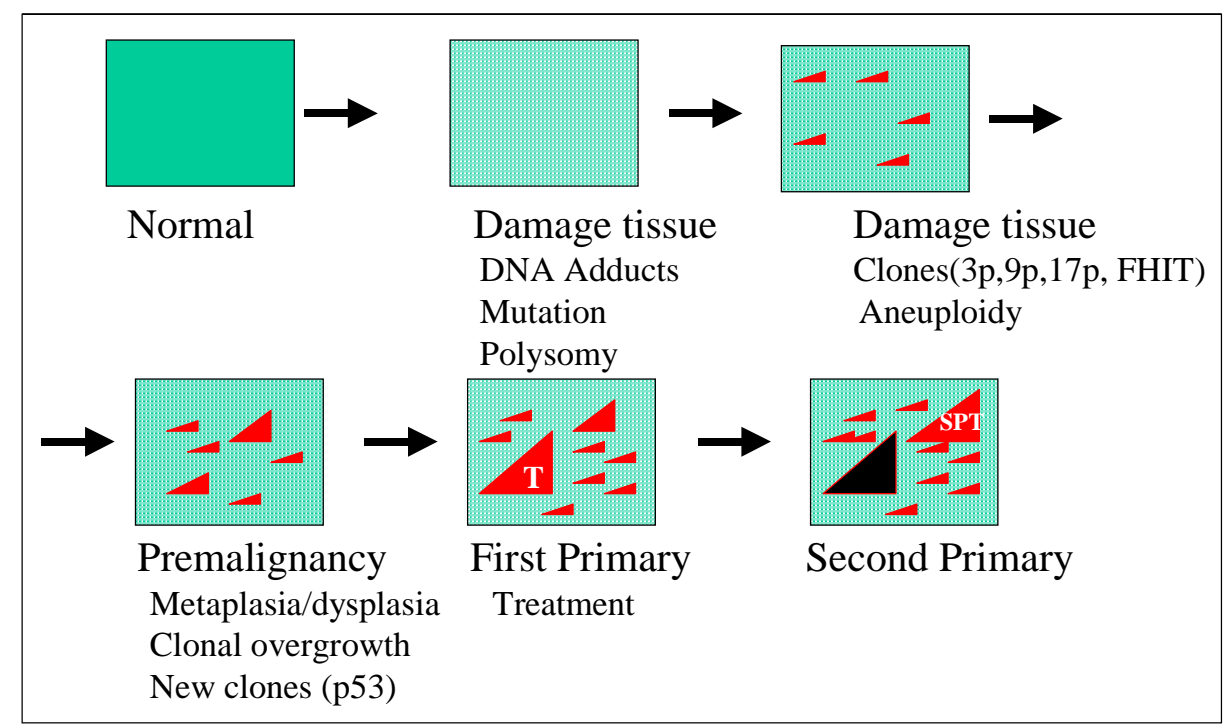

Fugure 3. Lung field cancerization \& multistep tumorigenesis.

진행의 위험도가 낮으므로 2 년마다 형광 기관지경을 실시하고, severe dysplasia인 경우는 3개월 뒤에 다 시 검사하여 계속 남아 있으면 치료를 실시하고 CIS 는 수술이나 기관지 내 치료를 바로 실시하라고 권하 였다. 일단 광역동치료를 포함한 기관지 내 치료 후 경과 관찰은 매 3-6개월마다 세심한 추적 기관지경 검사를 권장하고 있다.

Lam 등 ${ }^{18}$ 은 첫 보고에서 예민도가 백색 기관지경만 사용한 경우 $48 \%$ 에서 형광 기관지경 검사를 첨가하 면 73\%로 1.5배 향상되었음을 보고하였다. Häußinger 등 ${ }^{27}$ 은 무작위 대조 검사에서 일반 기관지경인 경우 예민도 $57.9 \%$ 이고 형광 기관지경은 추가한 경우 $82.3 \%$ 로 1.4 배 증가되었고 특이도는 $62.1 \%$ 에서 $58.4 \%$ 로 0.94 배 감소를 보고하였다. 국내 보고는 Jang 등 ${ }^{14}$ 이 일반 기관지경 예민도 $30.6 \%$ 이고 형광 기관지경은 추가한 경우 $72.9 \%$ 로 3.2 배 예민도가 증가하나 특이 도는 0.55 배 감소함을 보고하였다. 미국, 일본, 유럽의 여러 보고를 취합한 1,400 명 이상 검사를 종합하면 백 색 기관지경만으로는 high-grade dysplasia와 CIS 발 견율이 평균 $40 \%$ 정도 발견이 되나 형광기관지경을 첨가하면 $88 \%$ 까지 발견율을 높일 수 있다고 보고되 었다 ${ }^{24}$. 백색 기관지경과 형광기관지경 결과의 보고자 에 따른 차이는 일반 기관지경 발견율의 질적인 면과 병리학적 판정에 재현성 여부 차이 때문으로 설명한
다 ${ }^{28}$. 백색 기관지경의 발견율이 높으면 형광기관지경 의 예민도가 떨어지기 때문에 보고자에 따른 차이가 있다. 일반적으로 검사를 많이 하면 예민도는 높아지 는 반면 특이도는 상대적으로 떨어질 수 밖에 없어 형 광 기관지경을 실시하면 위양성 조직검사가 많아지는 문제점이 있다. 비용은 고려하지 않더라도 형광기관 지경의 단점은 특이도가 낮다는 점이다. 비정상 형광 을 보이는 약 $1 / 3$ 에서 위양성 반응을 보인다 ${ }^{21}$. 문제는 기관지경 검사 시간이 길어지고 병리검사 역시 시간 이 길어지는 문제를 유발한다 ${ }^{29}$. 이를 보완하기 위하 여 Quantitative fluorescence imaging 이나 combined fluorescence-reflectance imaging, AFI 등 특이도를 높이는 여러 가지 방법이 연구되고 있으나 실질적인 진전은 아직 미미하다. 그러나 위양성 조직 검사들 중 조직학적으로 정상적으로 보여도 비정상적으로 형광 을 보이는 점막은 분자 유전학적 변화가 $50 \%$ 까지 동 반되어 있다고 보고하고 있다으.

Kurie 등 ${ }^{31}$ 은 형광기관지경의 효과가 없음을 보고 하였다. 그들은 39 명의 흡연가와 이전 흡연가를 대상 으로 형광기관지경을 실시하여 squamous cell metaplasia 혹은 dysplasia의 발견율에 차이가 없음을 보고하였다. 다른 여러 결과와 상충한 이유는 연구 집 단에 진행성 폐암 환자가 너무 낮았고 중앙값 8년 전 에 금연을 실시한 대부분 금연가들이어서 발견율에 
차이가 있다고 생각된다. 그러나 폐암이 의심되고 dysplasia/CIS의 유병율이 높은 집단에서 형광 기관 지경 검사는 의미가 있다 ${ }^{19}$ 고 보고하고 있어 일반인을 대상으로 형광기관지경 검사는 적응이 되지 않는다.

그리고 형광기관지경은 비소세포폐암 환자에서 근 치적 수술을 실시한 환자에서 재발 감시 목적으로 사 용할 수 있다. 이시성 일차성 원발(second primary)폐 암이 폐암 수술 후 1-3\%정도 매년 발생하고 진단 당 시 $50 \%$ 정도만 제거가 가능한 상태에서 발견이 된다 32 . Weigel 등 ${ }^{33}$ 은 이전 수술을 실시한 25명의 환자를 대상으로 형광기관지경을 실시한 보고에서 $12 \%$ 환자 에서 다른 병변을 발견하였고 형광기관지경의 부가적 검사가 상대적 예민도를 3 배 증가시켰음을 보고하였 다. 비록 사망률의 감소를 증명하지는 못하였지만 field cancerization 이론이 조기 폐암 환자에서 수술 을 하기 전에 형광기관지경을 실시하는 것이 필요함 을 지지하여 준다. 그리고 수술 후 검사상 더 이상 병 변이 발견되지 않아 이전에 보이던 상피 내 병변이 퇴 행(regression)되었을 것으로 보고하였다 ${ }^{34}$. 다른 적응 증은 두경부 편평세포암 환자로 이들은 수술 후 37\% 까지 15년 내에 폐암이 발생한다. Venmans 등 35 은 두 경부 폐암 환자 중 이시성 일차성 원발폐암이 의심되 는 24 명에서 형광기관지경을 실시하여 $25 \%$ 에서 moderate-severe dysplasia를 발견하였고 예민도를 $21 \%$ 에서 $57 \%$ 로 증가시켰다. 또 다른 적응증은 치료 적 목적의 기관지 내 치료(intrabronchial therapy)를 실시한 환자에 적용이 될 수 있다. Sutedja 등 ${ }^{36}$ 은 흉 부 방사선 촬영상 보이지 않는 23 명의 CIS 환자에서 $\mathrm{CT}$ 로 기관지 주위 병변을 감별 후에 형광기관지경을 이용하여 6 명에서 종양의 침범 경계를 정확히 확인한 보고를 하였다. 이 환자들은 electrocautry로 치료하 였고 최장 50 개월까지 추적 경과 관찰 시 1 명의 환자 에서만 $\mathrm{CIS}$ 가 발생한 것 외에는 종양의 재발이 없었 다. 그 외 소세포 폐암 환자들 중 장기간 생존자. 40세 이상의 $\mathrm{COPD}$ 를 동반하거나 직업력이 있는 흡연가가 대상이 될 수 있겠다. 형광 기관지경의 향후 해결해야 할 문제는 아직 사망률을 줄인 결과가 없고, 특이도를 낮추는 많은 병변들(atropic area, ecchymosis, hyperemia, previous biopsy, scars, inflammation)에 감별
방법, 환자에서 질병의 유병률에 따른 발견율의 차이 점, 형광 기관지경 양상의 질적인 면, 검사자와 병리 학자의 재현성 차이에 따른 표준화의 작업 등 해결해 야 할 문제점이 아직 많은 상태이다.

\section{결 론}

이상의 결론으로 일반 기관지경에 부가적으로 자가 형광 기관지경을 사용하면 조기 병변의 발견율을 증 가시킨다. 형광기관지경을 일반인 모두에게 적용하기 는 무리가 있지만 고위험군을 포함한 환자들의 조기 검진 목적으로 사용될 수 있고 조기 폐암의 병인 기전 에 연구에 많은 도움을 줄 수 있는 유용한 장비이나 향후 기계적 질적 보완을 포함한 여러 연구가 필요한 상태이다.

\section{참 고 문 헌}

1. Shin HR, Ahn YO, Bae JM, Shin MH, Lee DH, Lee $\mathrm{CW}$, et al. Cancer incidence in Korea. Cancer Res Treat 2002;34:405-8.

2. Weir HK, Thun MJ, Hankey BF, Ries LAG, Howe HL, Wingo PA, et al. Annual report to the nation on the status of cancer, 1975-2000, featuring the uses of surveillance data for cancer prevention and control. J Natl Cancer Inst 2003;95:1276-99.

3. Saccomanno G, Archer VE, Auerbach O, Saunders RP, Brennan LM. Development of carcinoma of the lung as reflected in exfoliated cells. Cancer 1974;33:256-70.

4. Anderson GH, Boyes DA, Benedet JL, Le Riche JC, Matisic JP, Suen KC, et al. Organization and results of the cervical cytology screening programme in British Columbia, 1955-1985. Br Med J 1988;296: 975-8.

5. Winawer SJ, Zauber AG, O’Brien MJ, Ho MN, Gottlieb L, Sternberg SS, et al. for The National Polyp Study Workgroup. Randomized comparison of surveillance intervals after colonoscopic removal of newly diagnosed adenomatous polyps. N Engl J Med 1993;328:901-6.

6. Thunnissen FB. Sputum examination for early detection of lung cancer. J Clin Pathol 2003;5:805-10.

7. Bunn PJ Jr. Early detection of lung cancer using serum RNA or DNA markers: ready for "prime time" or for validation? J Clin Oncol 2003;21:3891-3.

8. Cortese DA, Pairolero PC, Bergstralh EJ, Wooler LB, 
Uhlenhopp MA, Piehler JM, et al. Roentgenographically occult lung cancer: a ten-year experience. J Thorac Cardiovasc Surg 1983;86:373-80.

9. Lam S, Mac Auley C, Le Riche JC, Ikeda N, Palcic B. Early localization of bronchogenic carcinoma. Diagn Ther Endosc 1994;1:75-8.

10. Nasiell M. Metaplasia and atypical metaplasia in the bronchial epithelium: a histopathologic study. Acta Cytol 1966;10:421-4.

11. Hayata Y, Kato H, Ono J, Matsushima Y, Hayashi N, Saito T, et al. Fluorescence fiberoptic bronchoscopy in the diagnosis of early stage lung cancer. Recent Results Cancer Res 1982;82:121-30.

12. Herth FJF, Ernst A, Becker HD. Autofluorescence bronchoscopy: a comparison of two systems (LFE and D-Light). Respiration 2003;70:395-8.

13. Lee SH, Shim JJ, Lee SR, Lee SY, Suh JK, Cho JY, et al. Useful of LIFE in diagnosis of bronchogenic cancer. Tuberc Respir Dis 1996;44:70-84.

14. Jang TW, Oak CH, Chun BK, Jung MH. Detection of pre-invasive endobronchial umors with D-light/Autofluorescence system. J Korean Med Sci 2006;21:242-6.

15. Kwon SJ, Lee YS, Jung MK, Lee YJ, Jang PS, Lee JE, et al. Primary synchronous lung cancer detected using autofluorescence bronchoscopy. Tuberc Respir Dis 2006;60:646-52.

16. Chiyo M, Shibuya K, Hoshino H, Yasufuku K, Sekine $\mathrm{Y}$, Lizasa $\mathrm{T}$, et al. Effective detection of bronchial preinvasive lesions by a new autofluorescence imaging bronchovideoscope system. Lung Cancer 2005;48: 307-13.

17. Ikeda N, Honda H, Hayashi A, Usuda J, Kato Y, Tsuboi M, et al. Early detection of bronchial lesions using newly developed videoendoscopy-based autofluorescence bronchoscopy. Lung Cancer 2006;52:21-7.

18. Lam S, MacAulay C, Hung J, LeRiche J, Profio AE, Palcic B. Detection of dysplasia and carcinoma in situ with a lung imaging fluorescence endoscope device. J Thorac Cardiovasc Surg 1993;105:1035-40.

19. Lam S, Hung JY, Kenney SM, LeRiche JC, Vedal S, Nelems B, et al. Detection of dysplasia and caicinoma in situ by ratio fluorometry. Am Rev Respir Dis 1992;146:1458-61.

20. Keith RL, Miller YE, Gemmill RM, Drabkin HA, Dempsey EC, Kennedy TC, et al. Angiogenic squamous dysplasia in bronchi of individual at high risk for lung cancer. Clin Cancer Res 2000;6:1616-25.

21. Hirsch FR, Prindiville SA, Miller YE. Franklin WA, Dempsey EC, Murphy JR, et al. Fluorescence versus white-light bronchoscopy for detection of preneoplastic lesions: a randomized study. J Natl Cancer Inst 2001;93:1385-91.
22. Woolner LB, Fontana RS, Cortese DA, Sanderson DR, Bernatz PE, Payne WS, et al. Roentgenographically occult lung cancer: pathologic findings and frequency of multicentricity during a 10-year period. Mayo Clin Proc 1984;59:453-66.

23. Sato M, Sakurada A, Sagawa M, Minowa M, Takahashi H, Oyaizu T, et al. Diagnostic results before and after introduction of autofluorescence bronchoscopy in patients suspected of having lung cancer detected by sputum cytology in lung cancer mass screening. Lung Cancer 2001;32:247-53.

24. Lam S, MacAulay JC, LeRiche JC, Palcic B. Detection and localization of early lung cancer by fluorescence bronchoscopy. Cancer 2000;89:2468-73.

25. Venmans BJW. van Boxem TJM, Smit EF, Postmus PE, Sutedja TG. Outcome of bronchial carcinoma in situ. Chest 2000;117:1572-6.

26. Bota SJ, Auliac C, Paris J, Metayer R, Sesboue G, Nouvet. Follow-up of bronchial precancerous lesions and carcinoma in situ using fluorescence endoscopy. Am J Respir Crit Care Med 2001;164:1688-93.

27. Häußinger K, Becker H, Stanzel F, Kreuzer A, Schmidt B, Strausz J, et al. Autofluorescence bronchoscopy with white light bronchoscopy compared with white light bronchoscopy alone for the detection of precancerous lesions: a European randomised controlled multicentre trial. Thorax 2005;60:496-503.

28. O’Neil KM, Johnson BE. Lights flicker on fluorescence bronchoscopy in patients at risk for lung cancer. $\mathrm{J}$ Natl Cancer Inst 1998;90:2468-73.

29. Kenndy TC, Lam S, Hirsch FR. Review of recent advances in fluorescence bronchoscopy in early localization of central airway lung cancer. Oncologist 2001;6:257-62.

30. Wistuba II, Lam S, Behrens C, Virmani AK, Fong $\mathrm{KM}$, LeRiche J, et al. Molecular damage in the bronchial epithelium of current and former smokers. J Natl Cancer Inst 1997;89:1366-73.

31. Kurie JM, Lee JS, Morice RC, Walsh GL, Khuri FR, Broxon A, et al. Autofluorescence bronchoscopy in the detection of squamous metaplasia and dysplasia in current and former smokers. J Natl Cancer Inst 1998;90:991-5.

32. Johnson BE. Second lung cancers in patients after treatment for an initial lung cancer. J Natl Cancer Inst 1998;90:1335-45.

33. Wigel TLS, Yousem S, Dacic S, Kosco PJ, Siegfried J, Luketich JD. Fluorescence bronchoscopic surveillance after curative surgical resection for non-small - cell lung cancer. Ann Surg Oncol 2000;7:176-80.

34. Wigel TLS, Kosco PJ, Dacic S, Rusch VW, Ginsberg RJ, Luketich JD. Postoperative fluorescence bron- 
choscopic surveillance in non-small cell lung cancer patients. Ann Thorac Surg 2001;71:967-70.

35. Venmans BJ, van Boxem TJM, Smit EF, Postmus PE, Sutedja TG. Bronchial intraepithelial neoplastic lesions in head and neck cancer patients: results of autofluorescence bronchoscopy. Ann Otol Rhinol
Laryngol 2001;110:635-8.

36. Sutedja TG, Codrington H, Risse EK. Breuer RH, van Mourik JC, Golding RP, et al. Autofluorescence bronchoscopy improves staging of radiographically occult lung cancer and has an impact on therapeutic strategy. Chest 2001;120:1327-32. 